PEDAGOGIA : Jurnal Ilmu Pendidikan

\title{
KEMAMPUAN GURU DALAM MELAKUKAN IDENTIFIKASI ANAK BERKEBUTUHAN KHUSUS
}

\author{
Dewi Ratih Rapisa \\ Universitas Lambung Mangkurat \\ rapisaratih@gmail.com
}

\begin{abstract}
The research departs from the problem of the average teacher lacks ability in identifying the obstacles experienced Children with Special Needs. Therefore, the need for the ability of teachers to identify Children with Special Needs in determining education services optimally. The goal to be achieved in this research is to find out how the ability of teachers in identifying children with special needs at Pasar Lama 3 Elementary School in Banjarmasin. In this research, the research approach used is qualitative descriptive approach. Research subjects in this study are principal, regular teachers and special need teachers at Pasar Lama 3 Elementary School in Banjarmasin. The results showed that teachers at Pasar Lama 3 Elementary School in Banjarmasin have not been able to do screening. Teachers do not provide tests to children using appropriate identification instruments. Teachers at Pasar Lama 3 Elementary School in Banjarmasin has been doing referral since the beginning of new students admission in school especially at the beginning of the first year of primary school and or grade increase. Teachers at Pasar Lama 3 Elementary School in Banjarmasin did not do classification because all the crew were directly served in the regular class.
\end{abstract}

Keywords: Children with Special Needs, identification skill

\begin{abstract}
Abstrak
Penelitian berangkat dari masalah rata-rata guru kurang memiliki kemampuan dalam mengidentifikasi kendala yang dialami Anak Berkebutuhan Khusus. Oleh karena itu, kebutuhan akan kemampuan guru untuk mengidentifikasi Anak Berkebutuhan Khusus dalam menentukan layanan pendidikan secara optimal. Tujuan yang ingin dicapai dalam penelitian ini adalah untuk mengetahui bagaimana kemampuan guru dalam mengidentifikasi anak-anak berkebutuhan khusus di Sekolah Dasar 3 SD di Banjarmasin. Dalam penelitian ini, pendekatan penelitian yang digunakan adalah pendekatan deskriptif kualitatif. Subjek penelitian dalam penelitian ini adalah kepala sekolah, guru reguler dan guru kebutuhan khusus di SD Pasar Lama 3 di Banjarmasin. Hasil penelitian menunjukkan bahwa guru di SD Pasar Lama 3 di Banjarmasin belum dapat melakukan skrining. Guru tidak memberikan tes kepada anak-anak menggunakan alat identifikasi yang tepat. Guru di Sekolah Dasar 3 SD di Banjarmasin telah melakukan rujukan sejak awal penerimaan siswa baru di sekolah terutama pada awal tahun pertama sekolah dasar dan atau peningkatan kelas. Guru di SD Pasar Lama 3 Banjarmasin tidak melakukan klasifikasi karena semua kru langsung dilayani di kelas reguler.
\end{abstract}

Kata Kunci: Anak Berkebutuhan Khusus, keterampilan identifikasi 


\section{A. PENDAhULUAN}

Anak Berkebutuhan Khusus (ABK) merupakan anak yang memiliki ciri yang berbeda dengan anak-anak pada umumnya, di mana mereka mengalami hambatan dalam pertumbuhan dan perkembangannya. Keberagaman karakteristik ABK yang tidak begitu mencolok dalam perbedaan, dapat menyebabkan guru mengalami kesulitan untuk mengenalinya. Dengan adanya ketidaktahuan guru dalam mengenali ABK di sekolah atau di kelasnya, maka hal ini akan berdampak bagi guru dalam memberikan layanan pembelajaran. Kesalahan dalam memberikan layanan kepada ABK karena ketidak tahuan guru, tidak dapat dianggap hanya hal sepele. Oleh karenanya, sekarang ini di beberapa perguruan tinggi termasuk di universitas terbuka yang mengelola program studi pendidikan calon guru sekolah dasar telah diberikan wawasan tentang $\mathrm{ABK}$, dengan harapan kelak bila mereka menjadi guru dapat memahami keberadaan dan dapat memberikan layanan bagi ABK di sekolah atau di kelasnya secara tepat. Penjelasan Pasal 15 Undang-undang Nomor 20 Tahun 2003 tentang Sistem Pendidikan Nasional menyebutkan bahwa pendidikan khusus merupakan penyelenggaraan pendidikan untuk peserta didik yang berkelainan atau peserta didik yang memiliki kecerdasan luar biasa yang diselenggarakan secara inklusi atau berupa satuan pendidikan khusus pada tingkat pendidikan dasar dan menengah. Identifikasi ABK diperlukan agar keberadaan mereka dapat diketahui sedini mungkin. Permasalahan yang timbul pada sekolah SDN Pasar Lama 3 saat ini rata-rata guru kurang memiliki kemampuan dalam mengidentifikasi ABK yang mengalami hambatan. Berdasarkan fenomena di atas, maka peneliti tertarik untuk melakukan penelitian dengan judul, "Kemampuan Guru Dalam Melakukan Identifikasi Anak
Berkebutuhan Khusus Di SDN Pasar Lama 3 Banjarmasin".

Berdasarkan uraian latar belakang masalah di atas, maka permasalahanpermasalahan di atas dapat diidentifikasi sebagai berikut di antaranya; guru-guru Sekolah Dasar terutama lulusan selain Pendidikan Luar Biasa (PLB) belum mendapatkan wawasan tentang pendidikan ABK. Selain itu, perlunya kemampuan guru untuk mengidentifikasi ABK dalam menentukan layanan pendidikan secara optimal. Oleh karena itu, berdasarkan uraian latar belakang masalah di atas, maka permasalahan dalam penelitian ini adalah bagaimanakah kemampuan guru dalam melakukan identifikasi anak berkebutuhan khusus di SDN Pasar Lama 3 Banjarmasin.

\section{B. KAJIAN LITERATUR}

Konsep anak berkebutuhan khusus memiliki arti yang lebih luas dibandingkan dengan pengertian anak luar biasa. Anak berkebutuhan khusus adalah anak yang dalam pendidikan memerlukan pelayanan yang spesifik, berbeda dengan anak pada umumnya. Anak berkebutuhan khusus ini mengalami hambatan dalam belajar dan perkembangan. Oleh sebab itu mereka memerlukan layanan pendidikan yang sesuai dengan kebutuhan belajar masing-masing anak.

Menurut Swassing (1985), identifikasi mempunyai dua konsep yaitu konsep penyaringan (screening) dan identifikasi aktual (actual identifikcation). Menurut Wardani (1995) dalam Munawir Yusuf, identifikasi merupakan langkah awal dan sangat penting untuk menandai munculnya kelainan atau kesulitan pada anak bekebutuhan khusus. Istilah identifkasi anak dengan kebutuhan khusus dimaksudkan sebagai usaha orang tua, guru, maupun tenaga kependidikan lainnya untuk mengetahui apakah seorang anak mengalami kelainan/penyimpangan pertumbuhan/ 
perkembangan (fisik, intelektual, sosial, emosional/tingkah laku) dibandingkan dengan anak normal seusianya.

Mengidentifikasi masalah berarti mengidentifikasi suatu kondisi atau hal yang dirasa kurang baik. Masalah pada anak ini diperoleh dari keluhan-keluhan orang tua dan keluarganya, keluhan guru, dan bisa didapat dari pengalamanpengalaman lapangan, Seperti dikatakan oleh Norman D.Sundberg (2002) dalam Tin Suharmini (2005). "Gathering informastion to be used for treatment (parents teachers, and physician) provide data on the childs functioning". Identifikasi dapat dilakukan oleh orangorang yang dekat (sering berhubungan/bergaul) dengan anak, seperti orang tuanya, pengasuhnya, gurunya, dan pihak-pihak lain.

Identifikasi secara harfiah adalah menemukan atau menemukenali. Setelah dilakukan identifikasi, kondisi seseorang dapat diketahui, apakah pertumbuhan dan perkembangannya normal atau tidak. Apabila mengalami kelainan atau penyimpangan, maka orang tua dapat mengelompokkan atau mengidentifikasi sebagaimana dalam kelompokknya, apakah termasuk anak tunanetra, tunarungu, tunawicara, tunagrahita, tunadaksa atau bahkan anak berbakat dan sebagainya. Dengan diketahui atau diidentifikasinya anak sejak dini maka orang tua tentu akan lebih baik dalam memberikan pelayanan selanjutnya apalagi kalau sampai dikatehui anak tersebut sebagai anak berkebutuhan khusus. Kegiatan identifikasi sifatnya masih sederhana dan tujuannya lebih ditekankan pada menemukan secara kasar apakah seorang anak tergolong anak dengan kebutuhan khusus atau bukan. Sebagaimana biasanya identifikasi dapat dilakukan oleh orang-orang yang dekat dengan anak, seperti orang tuanya, pengasuhnya, atau gurunya, maka orang tua dalam hal ini dapat melakukan identifikasi terhadap anaknya.
Secara umum tujuan identifikasi adalah untuk menghimpun informasi atau data apakah seorang anak termasuk anak berkebutuhan khusus atau tidak. Selain itu untuk menghimpun informasi apakah seorang anak mengalami kelainan/penyimpangan (fisik, intelektual, sosial, emosional, dan/atau sensoris neurologis) dalam pertumbuhan/perkembangannya dibandingkan dengan anak-anak lain seusianya (anak-anak normal). Menurut Swassing (1985) dalam Moch. Sholeh YAI (1996), tujuan prosedur identifikasi adalah merumuskan definisi; menentukan spesifikasi; menentukan prosedur, dan menempatkan anak. Sedangkan menurut Rice (1985), tujuan identifikasi adalah untuk menjabarkan karakteristik; merancang nominasi; menentukan alat tes dan penjaringan data; me-review kasus dan menentukan program; dan melakukan reevaluasi.

Dalam rangka pendidikan inklusi, kegiatan identifikasi Anak Berkebutuhan Khusus dilakukan untuk keperluan: penjaringan (screening); pengalihtanganan (referal); dan klasifikasi.

Penjaringan dilakukan terhadap semua anak dikelas. Pada tahap ini identifikasi berfungsi menandai anak-anak mana yang menunjukan gejala-gejala tertentu, kemudian menyimpulkan anakanak mana yang mengalami kelainan/penyimpangan tertentu, sehingga tergolong Anak Berkebutuhan Khusus. Dengan alat identifikasi ini guru, orang tua, maupun tenaga profesional terkait, dapat melakukan kegiatan penjaringan secara baik dan hasilnya dapat digunakan untuk bahan penanganan lebih lanjut.

Berdasarkan gejala-gejala yang dtemukan pada tahap penjaringan, selanjutnya anak-anak dapat dikelompokkan menjadi dua kelompok. Pertama, ada anak yang tidak perlu dirujuk ke ahli lain (tenaga 
profesional) dan dapat langsung ditangani sendiri oleh guru dalam bentuk layanan pembelajaran yang sesuai. Kedua, ada anak yang perlu dirujuk ke ahli lain terlebih dulu (referral) seperti psikolog, dokter, orthopedagog (ahli PLB), dan atau therapis, baru kemudian ditangani oleh guru. Proses perujukan anak oleh guru ke tenaga professional lain untuk membantu mengatasi masalah anak yang bersangkutan disebut proses pengalihtanganan (referral). Jika tenaga profesional tersebut tidak tersedia dapat diminintakan bantuan ke tenaga lain yang ada seperti Guru Pembimbing Khusus (Guru PLB) atau Konselor.

Pada tahap klasifikasi, kegiatan identifikasi bertujuan untuk menentukan apakah anak yang telah dirujuk ke tenaga profesional benar-benar memerlukan penanganan lebih lanjut atau langsung dapat diberi pelayanan pendidikan khusus. Apabila berdasar pemeriksaan tenaga profesional ditemukan maslaah yang perlu penanganan lebih lanjut (misalnya pengobatan, therapy, latihan-latihan khusus, dan sebagainya) maka guru tinggal mengkomunikasikan kepada orang tua siswa yang bersangkutan. Jadi guru tidak mengobati dan atau memberi therapy sendiri, melainkan menfasilitasi dan meneruskan kepada orang tua tentang kondisi anak yang bersangkutan. Guru hanya akan membantu siswa dalam hal pemberian pelayanan pendidikan sesuai dengan kondisi anak. Apabila tidak ditemukan tanda-tanda yang cukup kuat bahwa anak yang bersangkutan memerlukan penanganan lebih lanjut, maka anak dapat dikembalikan ke kelas semula untuk mendapatkan pelayanan pendidikan khusus. Kegiatan klasifikasi ini memilah-milah mana Anak Berkebutuhan Khusus yang memerlukan penanganan lebih lanjut dan mana yang langsung dapat mengikuti pelayanan pendidikan khusus di kelas reguler.

\section{METODOLOGI PENELITIAN}

Penelitian ini menggunakan pendekatan kualitatif dengan metode deskriptif. Penelitian kualitatif dimaksudkan untuk dapat mengetahui dan mendeskripsikan secara jelas dan rinci tentang kemampuan guru di SDN Pasar Lama 3 Banjarmasin dalam melakukan identifikasi Anak Berkebutuhan Khusus. Penggunaan metode deskriptif pada penelitian ini bertujuan untuk memperoleh gambaran subjek penelitian. Data kualitatif yang diperoleh dari hasil penelitian dapat dijadikan sebagai sumber deskriptif yang memuat penjelasan tentang proses yang terjadi dalam lingkungan penelitian. Data yang diperoleh secara kualitatif dapat mengikuti alur peristiwa secara kronologis menilai sebab akibat dalam lingkup pikiran subjek penelitian. Melalui metode deskriptif, peneliti mengkaji secara komprehensif terhadap fenomenafenomena dan kejadian yang terjadi di lokasi penelitian sesuai focus permasalahan yang telah ditentukan.

Penelitian dilakukan di SDN Pasar Lama 3 Banjarmasin. Subjek penelitian merupakan sumber data yang memberikan kejelasan mengenai duduk persoalan yang dikaji dan berdasarkan tingkat penguasaannya terhadap informasi yang akan diungkapkan informan yang mempunyai informasi lengkap dan cermat diutamakan menjadi subjek. Oleh karena itu, subjek penelitian ini adalah guru dan kepala sekolah.

Peneliti melibatkan diri secara langsung dalam menggali informasi yang berkaitan dengan data-data sesuai dengan pedoman yang digunakan. Intrumen yang digunakan dalam penelitian ini berupa angket sebagai instrumen pengumpulan data yang utama dan dilengkapi dengan pedoman observasi dan wawancara. Analisis data dalam penelitian ini menggunakan analisis 
deskriptif kualitatif yaitu proses penyederhanaan data ke dalam bentuk yang lebih mudah dibaca dan diinterpretasikan.

Teknik analisis data yang dilakukan adalah dengan mengolah hasil instrumen yang telah diisi oleh para guru, dan dipadukan dengan hasil observasi, wawancara serta dokumentasi.

\section{HASIL DAN PEMBAHASAN}

1. Hasil Penelitian

Berdasarkan hasil wawancara dan studi dokumentasi yang dilakukan peneliti mengenai kemampuan guru dalam melakukan identifikasi ABK di SDN Pasar Lama 3 Banjarmasin, maka diperoleh hasil penelitian yang bersifat informatif.

Berikut ini akan diuraikan secara detail hasil penelitian sesuai dengan pertanyaan penelitian:

a. Deskripsi Kondisi Objektif Kemampuan Guru dalam Melakukan Penjaringan (Screening) di SDN Pasar Lama 3 Banjarmasin Berdasarkan hasil studi dokumentasi guru tidak melakukan penjaringan (screening) dengan memberikan alat tes identifikasi hal ini dibuktikan dengan tidak adanya instrumen identifikasi yang dimiliki oleh guru. Dokumentasi yang terkumpul berupa hasil tes psikologi dari tim psikolog, jadi proses penjaringan (screening) seluruhnya di serahkan pihak sekolah ke psikolog. Guru hanya mengumpulkan dokumen berupa akta kelahiran, riwayat kelahiran, kartu keluarga dan hasil tes dari psikolog;

b. Deskripsi Kondisi Objektif Kemampuan Guru dalam Melakukan Pengalihtanganan (Referral) di SDN Pasar Lama 3 Banjarmasin Berdasarkan hasil studi dokumentasi, ada anak yang perlu dirujuk ke ahli lain terlebih dulu (referral) seperti psikolog, dokter, orthopedagog (ahli
PLB), dan atau therapis, baru kemudian ditangani oleh guru. Namun di SDN Pasar Lama 3 Banjarmasin, guru dalam melakukan pengalihtanganan (referral) tergantung pada hasil tes dari psikolog;

c. Deskripsi Kondisi Objektif Kemampuan Guru dalam Mengklasifikasi ABK di SDN Pasar Lama 3 Banjarmasin Berdasarkan hasil studi dokumentasi, kemampuan guru dalam menentukan mana ABK yang memerlukan penanganan lebih lanjut dan yang mana dapat mengikuti pelayanan pendidikan khusus di kelas reguler dilihat berdasarkan hasil pengamatan laporan perkembangan anak dan hasil tes psikologi ABK. Apabila berdasar pemeriksaan tenaga professional ditemukan maslaah yang perlu penanganan lebih lanjut (misalnya pengobatan, therapy, latihan-latihan khusus, dan sebagainya) maka guru tinggal mengkomunikasikan kepada orang tua siswa yang bersangkutan;

d. Deskripsi Kondisi Objektif Kendala yang dihadapi Guru dalam Melakukan Identifikasi ABK di SDN Pasar Lama 3 Banjarmasin Mengingat bahwa sekolah hanya baru 2 tahun merintis layanan pendidikan inklusif, maka guru belum memiliki pemahaman yang cukup tentang ABK sehingga dianggap guru belum kompetensi untuk memberikan tes kepada anak. Selain itu, guru belum memiliki instrumen identifikasi ABK. Oleh sebab itu, guru belum dapat menentukan mana yang ABK dan mana yang bukan. Selama ini, hal tersebut dilakukan dengan bantuan psikolog;

e. Deskripsi Kondisi Objektif Upaya Mengatasi Kendala Guru dalam Melakukan Identifikasi ABK di SDN Pasar Lama 3 Banjarmasin 
Berdasarkan hasil Focus Group Discussion (FGD) yang telah dilakukan oleh kepala sekolah, koordinator inklusi dan guru regular dari SDN Pasar Lama 3 Banjarmasin bersama ahli (dosen Pendidikan Luar Biasa Universitas Lambung Mangkurat), maka di antaranya terdapat beberapa upaya mengatasi kendala guru melakukan identifikasi ABK di SDN Pasar Lama 3 Banjarmasin, yaitu sebagai berikut.

1) Pertama, upaya mengatasi kendala yang dihadapi guru dalam melakukan penjaringan (screening) di antaranya yaitu perlu meningkatkan wawasan guru mengenai ABK agar dapat menyusun instrumen identifikasi sederhana yang fungsional.

2) Kedua, upaya mengatasi kendala yang dihadapi oleh guru dalam melakukan pengalihtanganan (referral) di antaranya yaitu perlu mengadakan in House Training (IHT) yang dapat diikuti oleh para guru secara keseluruhan mengenai pendidikan bagi ABK dan terutama prosedur melakukan identifikasi dan asesmen ABK.

3) Ketiga, upaya mengatasi kendala yang dihadapi oleh guru dalam mengklasifikasi ABK di antaranya yaitu alangkah lebih baik jika dapat memiliki konsultan atau pendamping sekolah inklusif yang berasal dar ahli sesuai dengan disiplin ilmunya.

2. Pembahasan

Berdasarkan hasil pembahasan sesuai dengan pertanyaan penelitian, berikut ini merupakan hasilnya.

a. Kemampuan Guru dalam Melakukan Penjaringan (Screening) di SDN Pasar Lama 3 Banjarmasin
Ada beberapa langkah dalam rangka pelaksanaan identifikasi anak berkebutuhan khusus. Identifikasi dapat dilakukan oleh orang-orang yang dekat (sering berhubungan/bergaul) dengan anak, seperti orang tuanya, pengasuhnya, gurunya, dan pihakpihak lain. Namun tahapan yang paling awal adalah melakukan penjaringan (screening). Menurut Swassing (1985) dalam Moch. Sholeh YAI (1996) bahwa penjaringan dilakukan terhadap semua anak dikelas. Pada tahap ini identifikasi berfungsi menandai anakanak mana yang menunjukan gejalagejala tertentu, kemudian menyimpulkan anak-anak mana yang mengalami kelainan/penyimpangan tertentu, sehingga tergolong Anak Berkebutuhan Khusus. Berdasarkan hasil wawancara dan studi dokumentasi pelaksanaan penjaringan (screening) di sekolah ini ternyata dilakukan oleh psikolog, jadi guru reguler maupun GPK tidak berperan langsung dalam proses penjaringan (screening). Jadi peran guru disini setelah ABK ditetapkan diterima, guru baru mengumpulkan data berupa riwayat kelahiran, data lengkap anak, data orang tua, akta kelahiran, kartu keluarga dan hasil tes psikologi kemudian di jadikan satu folder masing-masing ABK. Alasan dari pihak sekolah menggunakan psikolog dari luar di karenakan pihak sekolah masih merasa belum mampu melakukan identifikasi kepada ABK karena sekolah ini baru ditunjuk menjadi sekolah inklusif kurang lebih 2 tahun, dan saat itu masih belum ada guru yang berlatar belakang Pendidikan Luar Biasa, rata-rata guru berlatar belakang PGSD, BK, Ilmu Hukum dan lain- lain. Jadi penerimaan siswa ABK seluruhnya diserahkan ke 
pihak psikolog dan psikolog yang menentukan $\mathrm{ABK}$ mana yang diterima dan ditolak untuk pendidikan di sekolah ini.

b. Kemampuan Guru dalam Melakukan Pengalihtanganan (Referral) di SDN Pasar Lama 3 Banjarmasin

Dalam proses identifikasi setelah melakukan penjaringan (screening) tahap selanjutnya adalah melakukan pengalihtanganan (referral). Menurut Swassing (1985) dalam Moch Sholeh Y.A Ichrom, Ph. D mengatakan berdasarkan gejala-gejala yang dtemukan pada tahap penjaringan. Penelitian ini ternyata diperoleh informasi bahwa guru - guru di sekolah tersebut masih sangat sulit dalam melakukan pengalihtanganan (referral). Dari hasil instrumen wawancara dan studi dokumen yang diberikan kepada kepala sekolah, guru reguler dan GPK, jelas sekali kalau data tersebut menggambarkan guruguru belum memiliki kemampuan untuk melakukan pengalihtanganan (referral). Hal tersebut dikarenakan latar belakang pendidikan guru di sekolah tersebut kebanyakan bukan dari PLB. Jadi, dalam melakukan pengalihtanganan (referral) sekolah mengandalkan psikolog dari luar untuk melihat hasil dari kemampuan siswa ABK yang memerlukan perlakuan khusus.

c. Kemampuan Guru dalam Mengklasifikasi ABK di SDN Pasar Lama 3 Banjarmasin

Pada tahap klasifikasi, kegiatan identifikasi bertujuan untuk menentukan apakah anak yang telah dirujuk ke tenaga professional benarbenar memerlukan penanganan lebih lanjut atau langsung dapat diberi pelayanan pendidikan khusus. Berdasarkan hasil instrumen wawancara dan studi dokumen kemampuan guru dalam mengklasifikasi ABK dilakukan oleh GPK. Hal itu dilakukan berdasarkan hasil pengamatan dari perkembangan anak. Semua ABK yang berjumlah 20 siswa mendapatkan pelayanan pendidikan di kelas reguler dengan di dampingi GPK, jadi di sekolah tersebut tidak ada kelas khusus ataupun kelas transisi. Semua jenis hambatan pada ABK terlayani di kelas reguler.

d. Kendala yang dihadapi Guru dalam Melakukan Identifikasi ABK di SDN Pasar Lama 3 Banjarmasin

Langkah awal yang dilakukan dalam menemukan dan menentukan ABK di sekolah dasar adalah melalui identifikasi. Faktor yang mempengaruhi kemampuan guru dalam melakukan identifikasi anak berkebutuhan khusus di sekolah dasar penyelenggara pendidikan inklusi seperti di SDM Pakel ternyata dipengaruhi oleh banyak faktor. Guru di sekolah haruslah dapat memberikan layanan pendidikan pada setiap ABK, hanya sayangnya masih banyak guruguru di sekolah dasar yang belum memahami tentang ABK. Hal demikian tentu saja mereka juga tidak akan dapat memberirikan layanan pendidikan yang optimal.

e. Upaya Mengatasi Kendala Guru dalam Melakukan Identifikasi ABK di SDN Pasar Lama 3 Banjarmasin

Langkah pertama yang harus disiapkan dan diperhatikan adalah memberikan bekal kemampuan kepada guru-guru agar memiliki kemampuan mengidentifikasi ABK. Kemampuan identifikasi ini menjadi penting, sebab selengkap apapun fasilitas dan dana atau dukungan sekolah namun bila gurunya belum memiliki kemampuan membedakan, mengenali ABK maka 
jangan salahkan kalau akhirnya guru akan salah dalam penanganan selanjutnya. Hal tersebut, sejalan dengan yang disampaikan Hermanto (2008) bahwa mengasah kemampuan identifikasi anak berkebutuhan khusus ini dapat dilakukan kapan, dimana saja seperti dalam kelompok kerja guru, meminta penyuluhan ataupun mencari dan membaca referensi yang terkait dengan identifikasi anak berkebutuhan khusus.

\section{E. SIMPULAN DAN SARAN}

1. Simpulan

Berdasarkan hasil penelitian pada Bab sebelumnya, maka dapat ditarik kesimpulan sebagai berikut.

a. Guru di SDN Pasar Lama 3 Banjarmasin belum mampu melakukan penjaringan (screening). Guru tidak memberikan tes kepada anak dengan menggunakan instrumen identifikasi yang sesuai.

b. Guru di SDN Pasar Lama 3 Banjarmasin sudah melakukan pengalihtanganan (referral) sejak awal penerimaan siswa baru di sekolah khususnya pada masa awal tahun ajaran kelas $1 \mathrm{SD}$ dan atau kenaikan kelas. Oleh karena itu, guru tidak membuat database anak yang perlu pengalihtanganan dan database anak yang tidak perlu pengalihtanganan.

c. Guru di SDN Pasar Lama 3 Banjarmasin tidak melakukan klasifikasi karena seluruh ABK langsung dilayani di kelas regular.

d. Kendala yang dihadapi guru dalam melakukan identifikasi ABK, yang terdiri dari: Kendala yang dihadapi guru dalam melakukan penjaringan (screening), yaitu guru dianggap belum kompeten untuk melakukan identifikasi ABK secara mandiri; Kendala yang dihadapi guru dalam melakukan pengalihtanganan (referral), yaitu adanya anggapan kepala sekolah bahwa SDN Pasar Lama 3 Banjarmasin baru menyelenggarakan pendidikan inklusif terhitung sejak 2 tahun lalu tepatnya Mei 2015, sehingga saat ini sekolah masih sangat membutuhkan bantuan psikolog dan melimpahkan sepenuhnya layanan pendidikan khusus ABK kepada koordinator inklusi dan para GPK; dan Kendala yang dihadapi guru dalam mengklasifikasi ABK, yaitu masih terbatasnya bentuk layanan pendidikan khusus yang dapat diakomodasi oleh sekolah.

e. Upaya mengatasi kendala guru dalam melakukan identifikasi ABK, yang terdiri dari: Upaya mengatasi kendala yang dihadapi guru dalam melakukan penjaringan (screening), yaitu meningkatkan wawasan guru tentang $\mathrm{ABK}$ dan diadakannya pelatihan guru tentang penyusunan instrument identifikasi ABK; Upaya mengatasi kendala yang dihadapi guru dalam melakukan pengalihtanganan (referral), yaitu guru perlu membangun rasa percaya diri dan penerimaan diri terhadap keberadaan ABK di sekolah, sehingga guru dapat lebih percaya diri dan mandiri dalam menangani layanan pendidikan khusus walaupun tetap memerlukan masukan dan bantuan dari tenaga professional lainnya; Upaya mengatasi kendala yang dihadapi guru dalam mengklasifikasi $\mathrm{ABK}$, yaitu perlunya tambahan program layanan lanjutan bagi ABK yang memerlukannya dengan cara meningkatkan kompetensi guru melalui berbagai pelatihan dan dukungan sarana prasarana yang memadai. 
2. Saran

Berdasarkan hasil penelitian dan pembahasan serta kesimpulan yang telah dikemukan, berikut ini adalah beberapa saran yang diharapkan dapat menjadi masukan dan bahan pertimbangan, yaitu:

a. Bagi Sekolah

1) Perlu diadakannya pengenalan wawasan tentang anak berkebutuhan khusus.

2) Perlu dilakukan pelatihan identifikasi anak berkebutuhan khusus bagi guru reguler maupun GPK.

3) Perlu adanya diskusi terprogram yang difasilitasi oleh pihak sekolah bagi guru-guru ataupun semua yang terlibat dalam pendidikan inklusif di SDN Pasar Lama 3 Banjarmasin dan programprogram yang mendukung suksesnya program pendidikan inklusif di sekolah tersebut.

b. Bagi Peneliti Selanjutnya

Beberapa keterbatasan dalam penelitian ini, diharapkan kepada peneliti selanjutnya yang berminat melakukan penelitian dengan kajian yang sama diharapkan dapat lebih mengembangkan penelitian ini dengan mengambil cakupan wilayah penelitian yang lebih luas. Hendaknya menambah jumlah informan dalam penelitian ini, sehingga dapat menjadi pembanding untuk menggambarkan penelitian terhadap hasil dari kemampuan guru dalam melakukan identifikasi anak berkebutuhan khusus.

\section{DAFTAR PUSTAKA}

Abdurrahman, Mulyono. (1996). Pendidikan Bagi Anak Berkesulitan Belajar. Jakarta: Dirjen Dikti

Afrizal. (2014). Metode Penelitian Kualitatif. Jakarta: Raja Grafindo.
Bungin, B. (2003). Analisis Data Penelitian Kualitatif Pemahaman Filosofis dan Metodologis ke Arah Penguasaan Model Aplikasi. Jakarta: PT Raja Grafindo Persada.

Creswell, J.W. (1994). Research Design Qualitative and Quantitative Approaches. USA: Sage Publications.

Departemen Pendidikan Nasional. (2003). Undang-Undang Nomor 20 Tahun 2003, Tentang Sistem Pendidikan Nasional. Jakarta: Depdiknas.

Gallagher \& Kirk. (1986). Educating Exceptional Children 5 Edition. Boston: Hougton Mifllin Company.

Hemanto. (2008). Kemampuan Guru dalam Melakukan Identifikasi Anak Berkebutuhan Khusus di Sekolah Dasar Penyelenggara Pendidikan Inklusi. Dinamika Pendidikan No. 2/Th. XV/September 2008. 94-107.

Moch. Sholeh YAI. (1996). Identifikasi dan Pendidikan Dini Anak Berbakat. Jakarta: Depdikbud Dirjen DIKTI.

Munawir Yusuf. (2005). Asesmen Perkembangan pada Anak Tunagrahita. Jakarta: Departemen Pendidikan Nasional.

Sugiyono. (2014). Metode Penelitian Pendidikan Pendekatan Kuantitatif, dan $R \& D$. Bandung: Alfabeta.

Tin Suharmini. (2005). Penanganan Anak Hiperaktif. Jakarta: DIKTI.

Swassing, R. H. (1985). Teaching Gifted and Adolescents. Colombus Ohio: Charles E. Merril Publishing Company.

Wardani, I.G.A.K (1995). Metodelogi Bidang Studi. Jakarta: BP3GSD. 